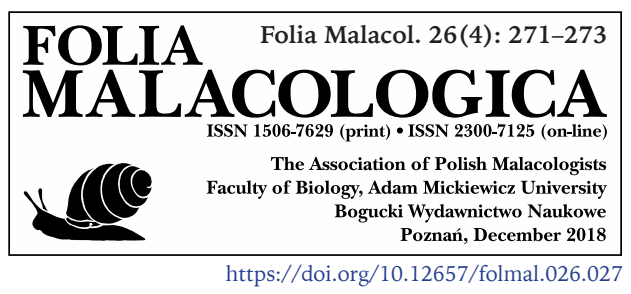

\title{
PETASINA UNIDENTATA (DRAPARNAUD, 1805) - A NEW SPECIES FOR THE MOLLUSC FAUNA OF THE ROZTOCZE UPLAND (SE POLAND)
}

\author{
MAŁGORZATA PROĆKÓW ${ }^{*}$, ElŻBIETA KuŹNIK-KOWALSKA²

\begin{abstract}
${ }^{1}$ Museum of Natural History, University of Wrocław, Sienkiewicza 21, 50-335 Wrocław, Poland (e-mail: malgorzata.prockow@uwr.edu.pl)

${ }^{2}$ Department of Invertebrate Systematics and Ecology, Institute of Biology, Wrocław University of Environmental and Life Sciences, Kożuchowska 5b, 51-631 Wrocław, Poland

(e-mail: elzbieta.kowalska@upwr.edu.pl)

*corresponding author
\end{abstract}

\begin{abstract}
The hygromiid land snail Petasina unidentata (Draparnaud, 1805) was found in a new locality in south-eastern Poland. The site is located in the Czartowe Pole Nature Reserve, outside the continuous distribution range of the species and represents its easternmost occurrence. Given its ecological preferences for woodlands, it is unlikely that the species is a recent anthropogenic introduction. It may be rather considered as a postglacial or even interglacial immigrant and thus relict species.
\end{abstract}

KEY WORDS: distribution, Hygromiidae, land snails, new locality

Petasina unidentata (Draparnaud, 1805) is an EastAlpine and Carpathian species. Its distribution range includes eastern and north-eastern Switzerland, Alpine regions of Germany (with single localities in the north to the Main River, Erzgebirge), whole Austria, the Danube valley, the Carpathians and Bohemian Massif in the Czech Republic and Slovakia (POLIŃSKI 1928, KERNEY et al. 1983, TURNER et al. 1998). It is also found in northern Italy (MANGANELLI et al. 1995) and northern Hungary. In Poland its occurrence extends from the Sudetes, through CracowWielun Jura, the Carpathians (except Bieszczady Mts) reaching the Wisłoka River in the east (RIEDEL 1988). It lives in damp montane forest habitats between 500 and $1,500 \mathrm{~m}$ a.s.l., being also quite frequent above the timberline, up to $2,000 \mathrm{~m}$ a.s.l. It is found along streams in leaf-litter, rotting wood and, rarely, on vegetation (PROĆKów 2009).

The new site of $P$. unidentata is located in the valley of the Sopot River in the Czartowe Pole Nature Reserve (50²6'29"N, 2305'59"E, $240 \mathrm{~m}$ a.s.l., Fig. 1) in the Polish part of the Roztocze Upland, which is a range of hills in south-eastern Poland and western Ukraine, and constitutes a ridge in the northern forefield of the Carpathians. Two live adult individuals (with well-developed tooth) of $P$. unidentata were found in a riparian forest. The snails stayed in leaf-litter among perennial herbs. This is a typical habitat of the species, which is regarded as an important indicator of humidity (HORSÁK et al. 2013), sensitive to human impact (BŘízOVÁ \& JUŘIČKOVÁ 2011). Nevertheless, P. unidentata was also recorded in drier types of floodplain forests (ČEJKA \& HAMERLIK 2009) as well as in anthropogenic habitats (ZAJĄC 2014, ČEJKA 2018). Besides at the sampling site Czartowe Pole P. unidentata was accompanied by few specimens of such species as Nesovitrea hammonis (Ström, 1765), Discus rotundatus (O. F. Müller, 1774), Bulgarica cana (Held, 1836), Fruticicola fruticum (O. F. Müller, 1774), Monachoides vicinus (Rossmässler, 1842), M. incarnatus (O. F. Müller, 1774) and Perforatella bidentata (Gmelin, 1791). Most of them are forest species and snails preferring damp habitats. Small snail species were not recorded because sieving was not performed, and only this method enables to detect them. 


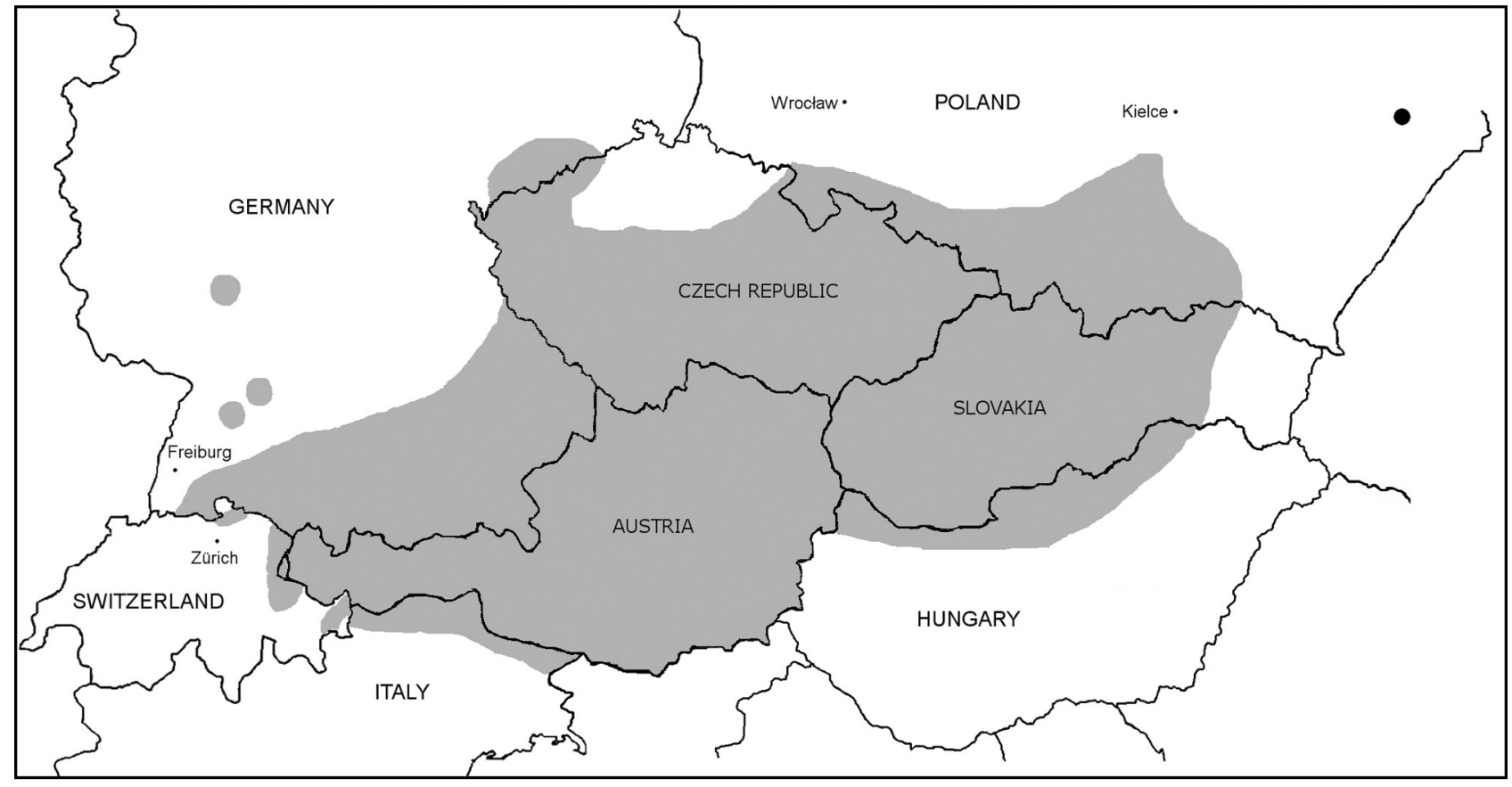

Fig. 1. Distribution range of Petasina unidentata after PRoćKów (2009) and the new locality described here (black dot)

P. unidentata varies greatly in its shell dimensions (shell height 3.4-6.6 mm, shell width $5.1-9.5 \mathrm{~mm}$, aperture height $1.7-3.2 \mathrm{~mm}$, aperture width $3.0-5.2$ $\mathrm{mm}$, umbilicus diameter $0.2-0.8 \mathrm{~mm}$, umbilicus diameter/shell diameter ratio 0.03-0.11, PROćKów 2009). The shell measurements of the specimens from the study site are in the lower limits of their size: shell height $3.9-4.8 \mathrm{~mm}$, shell width $6.4-6.7$ $\mathrm{mm}$, aperture height $1.9-2.3 \mathrm{~mm}$, aperture width 3.3-3.8 $\mathrm{mm}$. The umbilicus is partly or almost entirely covered by the columellar aperture margin in these two snails. The shells are covered with dense and fine hairs (Fig. 2).

Although, the Roztocze Upland was the subject of earlier research, $P$. unidentata had not been found in this area (SKURATOWICZ \& URBAŃSKI 1953, KOWALSKI et al. 1963, PIECHOCKI 1990). The record of $P$. unidentata is the easternmost location outside the
Polish Carpathians and represents an extension of its range. The nearest record comes from the Wisłoka River, situated ca. $200 \mathrm{~km}$ away (RIEDEL 1988). Given ecological preferences of $P$. unidentata for woodlands, it is unlikely that the species is a recent anthropogenic introduction. P. unidentata as well as a number of other thermophilous and woodland species found earlier in the Roztocze Upland, such as Discus perspectivus, Macrogastra tumida, M. latestriata, Balea fallax and Perforatella dibothrion, are most likely postglacial immigrants expanding from their refugia in the Carpathians. Therefore, they may be considered as relics in the Roztocze Upland (PIECHOCKI 1990). However, it cannot be ruled out that $P$. unidentata may also be an older, interglacial relic. There are several known examples of Carpathian and East-Alpine species, which during the great interglacial period expanded their distribution range (URBAŃSKI 1948).
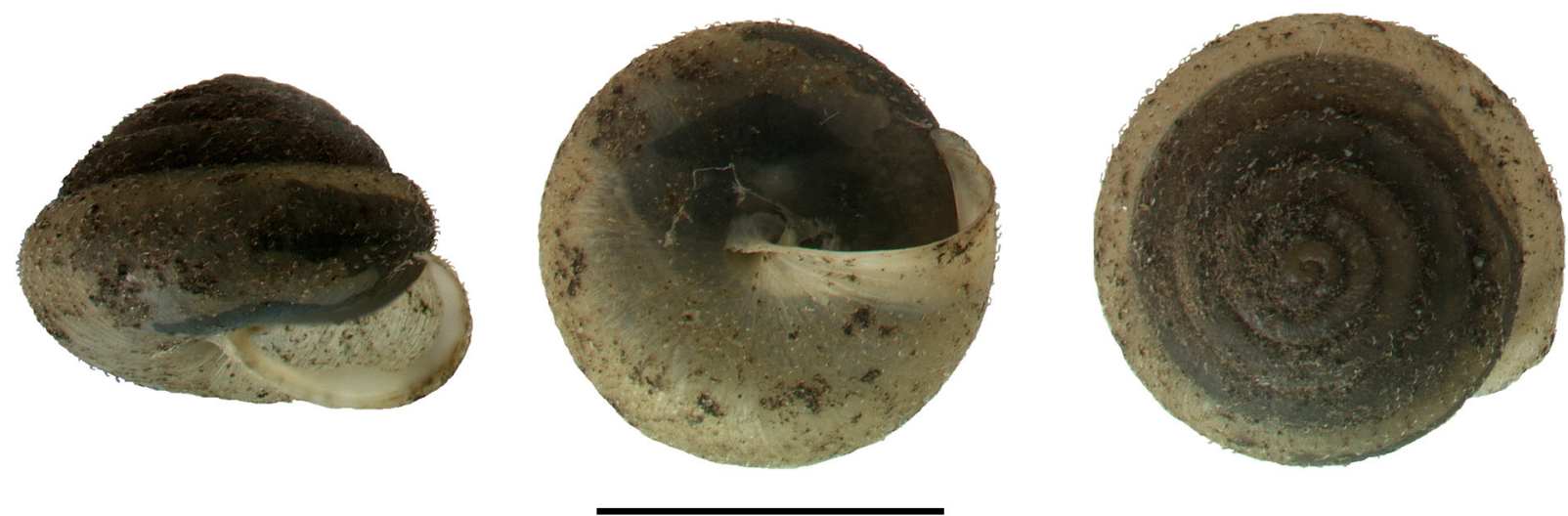

Fig. 2. Shell of Petasina unidentata from Czartowe Pole in apertural, umbilical and apical views. Scale bar $5 \mathrm{~mm}$ 


\section{REFERENCES}

BŘízovÁ E., JUŘIČKOVÁ L. 2011. Could canopy forests survive agricultural colonization in the Polabi lowland (Czech Republic). Bulletin of Geosciences 86: 283-300. https://doi.org/10.3140/bull.geosci.1260

ČEJKA T. 2018. Ulitníky izolovaných častí bratislavského lesoparku. Naturae Tutela 22: 79-92.

ČEJKA T., HAMERLÍK L. 2009. Land snails as indicators of soil humidity in Danubian woodland (SW Slovakia). Polish Journal of Ecology 57: 741-747.

HORSÁK M., JUŘIČKOVÁ L., PICKA J. 2013. Měkkýši České a Slovenské republiky. Molluscs of the Czech and Slovak Republics. Kabourek, Zlín.

Kerney M. P., CAmeron R. A. D., Jungbluth J. H. 1983. Die Landschnecken Nord- und Mitteleuropas. Paul Parey, Hamburg und Berlin.

KOWALSKI K., MŁYNARSKI M., WiKTOR A., WOŁOSZYN W. 1963. Postglacjalna fauna $z$ Józefowa, pow. Biłgoraj. Folia Quaternaria 14: 1-26.

MANGANELli G., BOdON M., FAVILLI L., GiUSTI F. 1995. Fascicolo 16. Gastropoda Pulmonata. In: MiNELLI A., RufFo S., LA POSTA S. (eds). Checklist delle specie della fauna italiana. Calderini, Bologna, pp. 1-60.

PIECHOCKI A. 1990. Interesujące gatunki ślimaków lądowych (Gastropoda terrestria) na Roztoczu. Przegląd Zoologiczny 34: 237-247.

POLIŃSKI W. 1928. Sur certains problèmes du development morphologique et zoogéographique de la faune des Alpes et des Karpates illustrés par l'étude détaillée des
Hélicidés du groupe Perforatella auct. Annales Musei Zoologici Polonici 7: 137-229.

ProćKów M. 2009. The genus Trochulus Chemnitz, 1786 (Gastropoda: Pulmonata: Hygromiidae) - a taxonomic revision. Folia Malacologica 17: 101-176. https://doi. org/10.2478/v10125-009-0013-0

RIEDEL A. 1988. Ślimaki lądowe Gastropoda terrestria. Katalog Fauny Polski 36. PWN, Warszawa.

SKURATOWICZ W., URBAŃSKI J. 1953. Rezerwat leśny na Bukowej Górze koło Zwierzyńca w województwie Lubelskim i jego fauna. Ochrona Przyrody 21: 193-216.

Turner H., Kupier J. G. J., TheW N., Bernasconi R., RÜETTSCHI J., WÜTHRICH M., GOSTELI M. 1998. Atlas der Mollusken der Schweiz und Liechtensteins, Fauna Helvetica 2. Centre suisse de cartographie de la faune, Neuchâtel, Switzerland.

URBAŃSKI J. 1948. Reliktowe mięczaki ziem polskich i niektórych krajów przyległych. Ochrona Przyrody 18: 6695.

ZAJĄC K. 2014. The mollusc fauna of Żywiec town (southern Poland). Folia Malacologica 22: 209-220. https:// doi.org/10.12657/folmal.022.013

Received: November 16th, 2018

Revised: November 26th, 2018

Accepted: November 27th, 2018

Published on-line: December 11th, 2018 